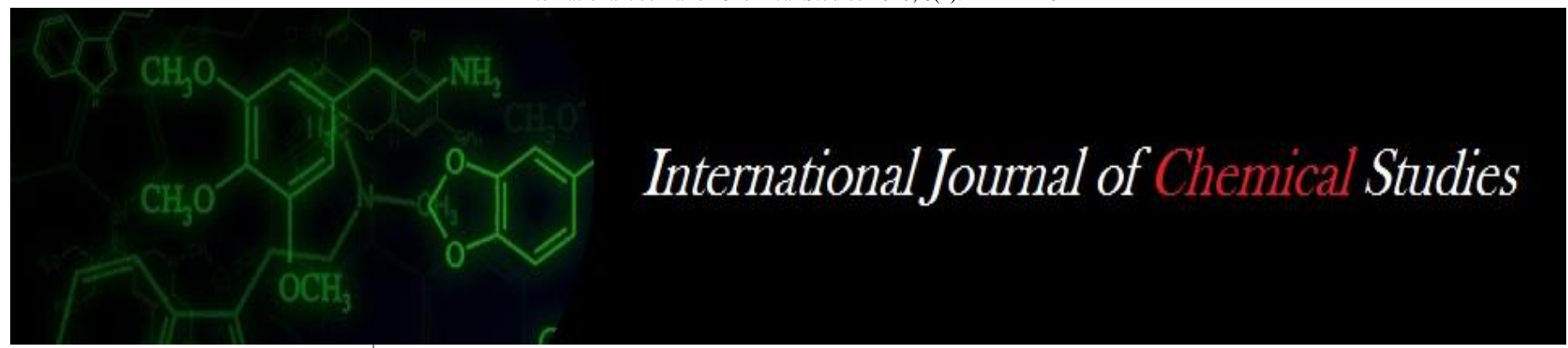

P-ISSN: 2349-8528

E-ISSN: 2321-4902

www.chemijournal.com

IJCS 2020; 8(2): 2414-2416

(C) 2020 IJCS

Received: 01-01-2020

Accepted: 05-02-2020

Satya Prakash

SVPUA\&T, Meerut, Uttar

Pradesh, India

Devendra Pal

KVKSAMBHAL SVPUA\&T,

Meerut, Uttar Pradesh, India

Bijendra Singh

SVPUA\&T, Meerut, Uttar

Pradesh, India

Atar Singh

ICAR, ATARI, Kanpur, Uttar

Pradesh, India

\section{Role of Krishi Vigyan Kendra's for doubling the farmers income through transfer of technologies}

\author{
Satya Prakash, Devendra Pal, Bijendra Singh and Atar Singh
}

DOI: https://doi.org/10.22271/chemi.2020.v8.i2ak.9110

\begin{abstract}
To increase the crop productivity, there are so many factors like soil quality, seeds, climate, water and inputs. Due to continuous growing of crop, the productivity of the soil keeps on decreasing resulting in less productivity overall. Which increases the cost of cultivation resulting in less net return to the farmers. The changing climate conditions had also affected the crop productivity in present scenario. Keeping all this in the view ICAR gave Krishi Vigyan Kendra's the responsibility to provide the new technologies with different activities like training, FLDs, CFLDs, OFT and different awareness programmes (Pradhan Mantri Fasal Bima Yojna-PMFBY, Rabi and Kharif crop Abhiyan etc.). The scientists from KVKs are going in the farmer's fields to diagnose the problems and giving them solutionsin simplified manners. KVKs also played a significant roles in preparing and distributing the soil health cards (SHC). The pulses production also became sufficient at the national level with the support of the KVKs. On the basis of all what is mentioned above, we can conclude that KVKs are playing a significant role towards the transfer of technical knowledge.
\end{abstract}

Keywords: PMBFY, SHC, CFLDs, KVKs

\section{Introduction}

In present scenario Agricultural Innovation and diffusion of new Technologies are important factor for increasing the production and productivity Farming in different resource endowment must be sustainable, economical and intensive in order to provide dependable and long term support for rural households. Because there are much gaps in Production and productivity without adopting newly technologies, farmers are unable to get the good return and inputs cost are increasing day by day.

To achieve these capabilities, farmers must have access to sustainable technologies in crops, livestock and fisheries sectors. In this regard the ICAR has established a network of more than 715 Krishi Vigyan Kendra's (KVK's) covering whole district of the country and these KVK's are functioning as knowledge resource centre at district level. Although some districts have two KVK's.

\section{Krishi Vigyan Kendra's (KVK's)}

The KVK's have been established in different host organization are given below:

1. State Agricultural University (SAU's).

2. Central Agricultural University.

3. ICAR Institutes.

4. Non-Government Organization.

5. Other Educational Institute (OEI).

All KVK's are $100 \%$ by ICAR New Delhi and maximum KVK's are established by SAU's in the country.

\section{Function / Mandates of KVK's:}

KVK's are functioning to conduct technology assessment, refinement and demonstration through various activities. KVK has over the years evolved as an effective and well tested frontline extension system which is exemplary and admired all over the country, but demands and technological challenges of various types of clients and to reach the rural poor (Rinera et. al. 2001: Davis 2008: Birner et al. 2009). A number of technologies developed in agriculture 
and allied sector do not readily reach the farmers due to low extension worker and farmer ratio and poor delivery mechanism. Over the past six decades, the ICAR has piloted several innovative extension approaches through Krishi Vigyan Kendra's. Out of this many of these approaches have successfully been upscaled and integrated into the transfer of technologies through Krishi Vigyan Kendra's, some are given below:

1. National Extension Programme (NES): It is started by Extension Division of IARI. In this programme ICAR Institutes, Sau's and other Institutes are involving the transfer of Technologies to the stake holders. Extension division of IARI decided to involve the KVK's for success fully Implementation of the project to the rural farmers. More than $15 \mathrm{KVK}$ 's are functioning the transfer of technologies effectively under this project. All newly technologies of cereals, pulses, horticulture, oilseeds of routine cultural are successfully transfer to the farmer for increasing or doubling the farmers' income.

2. Cluster front line Demonstrations (C.L.F.D.): To full fill the needs of oils \& pulses government of India started special programme cluster from line demonstration (CFLD) of oil seeds and Pulses. In this system farmers are selected in cluster basis and all techniques like inter function of newly varieties, production techniques introduced in cluster. Due to cluster based approach new techniques easily transfer to the farmers. Resulting productivity of crops increased significantly.

3. Post office linkages programme (P.O.L.P.): To increase the profitability of the farmers post office linkage programme started by ICAR through actively involvement of the department of post office for his services. In this project the inputs (Seeds and bio pesticides etc) are supplied through Post office. To success full transfer of technologies Krishi Vigyan Kendra's were also part of this project. Krishi Vigyan Kendra's play the active role for transfer of technologies through trainings, demonstrations, field days, Inputs arrangement, implementation and documentation etc. due to timely availability of quality seeds and production technologies farmers are getting higher production.

4. Soil health card (S.H.C.): To maximum return through decreasing the production cost and increase the production Government of India (GOI) has decided to provide the Soil Health Card (S.H.C.) on soil testing basis to the farmers on the grid basis, the size of grid depend on Irrigation facility. In this system soil samples collected \& tested and Soil Health Care issues to all farmers of concerned grid. G.O.I. has also decided to contribute Soil Health Card through Krishi Vigyan Kendra's. Every Krishi Vigyan Kendra's played the active role towards issuing the soil health card and created awareness through celebrating World Soil Health Day (5 December) as per direction of ICAR. K.V.K's Scientists are focusing the use of fertiliser on the soil testing based. Farmers start the fertilizer utilization as per recommendation giving in his soil health card. Now they are getting more yields per unit area in comparison to previous.

5. Prime Minister Fasal Bima Yojna (PMFBY): Prime Minister Fasal Bima Yojna was started in 2016,
Government of India gave the awareness responsibility of PMFBY to Krishi Vigyan Kendra's. Most of Krishi Vigyan Kendra organized the awareness programme as per date decided by Hon'ble Member of Parliament (M.P.) of that Area. The awareness programme of PMEBY successfully were organised by each K.V.K's in his district including 800-1000 farmers in chairmanship of Hon'ble member of parliament (M.P.)with the support of K.V.K's. Farmers are benefited by PMFBY and increasing his productivity.

6. Unnati Krishi Mela (UKM): Unnati Krishi Mela continuously organised by ICAR every year for providing the newly developed technologies to the farmers. To successfully transfer of agricultural technologies ICAR also give the responsibility to the K.V.K's to ensure the farmers participation from each district. K.V.K's are continuously playing the responsibility and farmers are benefitted by newly technologies by seeing and convinced and start adopting newly technologies. Through newly seeds and technologies they are getting more production and return.

7. National Food Security Mission (NFSM): Government of India started the National Food Security Mission(NFSM)for increasing the productivity of the different crops. In this mission Krishi Vigyan Kendra's are playing the role as expert and provide the technologies to the farmers in different programmes held in district. Besides this K.V.K's Head is also expert member in district label committee for the successful implementation of the mission. On the Above basis its proves that K.V.K's are playing the significant role to increasing the farmers income.

8. National Horticulture Mission (NHM): To the successfully implementation of National Horticulture Mission(NHM) KVK scientists are playing the role as expert in different activities like trainings, Gosthies and Kisan Mela etc. and provides the technologies to the farmers and also solve the technical problem raised by the farmers and as expert member in district level committee. Its proves that Krishi Vigyan Kendra's scientists are fully involve for doubling the farmers income.

9. Community Radio Station (CRS): Now a days community Ratio Station (CRS) is strong media for transfer of technologies. Farmers are getting newly technology daily and solve their problems by asking the question by expert. Some Krishi Vigyan Kendra's established the CRS at KVK centre with the support Department of Agriculture under Agricultural Technology Management Agency (ATMA). KVK's scientists delivered the technical talks per day as demanded by the farmers and solve their raised problems. It is proved that Krishi Vigyan Kendra's are also involved in transfer of agricultural technology through CRS and involve the increasing farmer's income.

10. Farmers Producer Organization (FPO): It has proven that farmers income can be increase through Farmers Producer Organization (F.P.O.). Scientists of Krishi Vigyan Kendra's are Supporting to line department for promotion of FPO and time to time giving the technical 
support during formation and successfully implementation so that then can earn maximum return in his FPO's. Presently FPO on seed production, Dairy, Organic vegetables and bio fertilizers, Honey production etc are successfully working with the technical support of K.V.K's scientists and they are increasing his income through FPO's.

11. Mahila Kisan Diwas: Presently women population is about $49 \%$ of the total population. To increase the agriculture productivity through effectively involvement of the women in agriculture ICAR New Delhi has decided to celebrate the Mahila Kisan Diwas on $15^{\text {th }}$ October every year at Krishi Vigyan Kendra's. Till date all Krishi Vigyan Kendra's are celebrated Mahila Kisan Diwas every year at KVK's. On this programme technology are provided to Agricultural women's and honoured the progressive women in this occasion so that they can adopt newly technology in her fields and also provide the technical knowledge to other women. So that income of farmers can be increases.

12. Sankalp Se Siddi for doubling the farmer's Income: As per decision of Hon'ble Prime Minister Sri Narendra Modi ji Government of India is celebrating "Sankalp se Sidi programme" in the month of July-August every year till 2017 through whole KVK's of the country in chairmanship of local Member of Parliament (MP) for doubling the farmers income. In this program Krishi Vigyan Kendra's Scientist are engaged to Transfer the Technical inputs easily to the farmers. In this programme 700-900 farmers participating and official of the line department also participated. Through this system technology continuously easily reached to the farmers and they are increasing their income with the support of Krishi Vigyan Kendra's.

13. Kisan Kalyan Diwas: As per decision of Hon'ble Prime Minister Sri Narendra Modi ji Government of India, ICAR New Delhi directed to all KVK's to organise the Kisan Kalyan Diwas in the month of May 2018 in the presence of nominated Minister. In this regards Kisan Kalyan Diwas organised by whole K.V.K.s of country in the presence of the ministers and review the K.V.K's Work in the prescribed format. Most of ministers appreciate the work of K.V.Ks. In this programme line department officials and average 300 farmers were participated in each K.V.K's. On the above basis it's proves that Krishi Vigyan Kendra's are Fully Devoted to the Doubling the Farmers income through transfer of Technologies.

Conclusion: Newly Technologies are continuously transferred by K.V.K's to the farmers through different mechanism including T.V. talks, Radio talks, media coverage for the increasing productivity of Cereals, Pulses, Oilseeds, Horticultural crops, Livestock's and Fisheries in all over India and play the key role towards prosperity of the farmers. Now days role of K.V.K's are recognized every plate farm in significantly. Recently K.V.K's have worked as a milestone towards increasing the pulses production.

On the above base its proved that Krishi Vigyan Kendra are playing the significant role for in doubling the farmers income through transfer of agricultural technologies.

\section{References}

1. Bimer RK, Davis J, Pender EN, Kanya P, Anandajayasekar Ekboir J. From best practices to best fit: A Frame work for Designing and analyzingplaralistic Agricultural Advisory Service World wide J of Agril and Ext. Edu. 2009; 15(u):341-355.

2. Daws K. Extension in seed soharan Africa: overview and Assessment of post and current models and future prospects J of Agril and Ex-Edu. 2008; 15(3):15-28.

3. Revera WMKM, Qmar LV. erduder Agricultural and rural extension worldwide: options for Institutional Reform in Developing countries Rome. CAO, 2001. 